This item was submitted to Loughborough's Research Repository by the author.

Items in Figshare are protected by copyright, with all rights reserved, unless otherwise indicated.

\title{
From New York to Shanghai: global modernism, cheap reprint series and copyright
}

PLEASE CITE THE PUBLISHED VERSION

https://doi.org/10.3366/mod.2018.0197

PUBLISHER

(C) Edinburgh University Press

VERSION

AM (Accepted Manuscript)

\section{PUBLISHER STATEMENT}

This work is made available according to the conditions of the Creative Commons Attribution-NonCommercialNoDerivatives 4.0 International (CC BY-NC-ND 4.0) licence. Full details of this licence are available at: https://creativecommons.org/licenses/by-nc-nd/4.0/

\section{LICENCE}

CC BY-NC-ND 4.0

\section{REPOSITORY RECORD}

Jaillant, Lise. 2019. "From New York to Shanghai: Global Modernism, Cheap Reprint Series and Copyright". figshare. https://hdl.handle.net/2134/24657. 


\title{
From New York to Shanghai: Global Modernism, Cheap Reprint Series and Copyright
}

\author{
Lise Jaillant
}

In February 2015, Le Monde published an article on Chimamanda Ngozi Adichie’s latest novel, Americanah, which had just been translated into French. 'Although nobody in France knows it yet,' declared the article, 'Adichie is a star' whose novel sold 500,000 copies in the US and Britain. ${ }^{1}$ In Nigeria, her country of origin, Adichie still has a small audience, but global publishing has expanded her readership to the marketplace of the world. Arguably, the international appeal of her work derives from her combination of a cosmopolitan, urban aesthetic with a use of local colour that manifests as 'strategic exoticism,' to use Graham Huggan's term. ${ }^{2}$ For Huggan, Sarah Brouillette and others, a tension is thus created between global and local readerships in which local interests are sometimes sacrificed so that the larger audience can be won. ${ }^{3}$

Flashback to modernism, and the first real beginnings of the international publication and translation of fiction. Despite obvious differences, numerous modernist writers were in the position of Adichie today, with local readerships confined to small presses and little magazines, but with promising possibilities for global expansion. And, like some postcolonial authors, when modernists signed deals with mainstream publishing houses, they were often accused of changing their style with an eye on the marketplace (take Gertrude Stein and her Autobiography of Alice B. Toklas, published by Harcourt Brace in 1933). What commercial publishers offered was access to global distribution networks and expertise in marketing and copyright laws. While the small press of Ben Huebsch struggled to make modernist texts by James Joyce and others available even locally, Random House or Harcourt Brace could reach a global readership. Large-scale publishers were also better equipped to fight legal battles against charges of obscenity, and to adapt their strategies to various national contexts more or less tolerant of daring modernist texts. Not only did they sell Anglophone modernism to the world; they also published translations of experimental texts in Russian, Chinese and other languages. These translations, in turn, influenced Anglophone writers.

The recent interest in 'global modernism' has led to a wave of studies, focusing for example on 'cosmopolitan style' or 'transnational poetics. ${ }^{4}$ While modernist scholars have explored the theoretical aspects of globalization in relation to the literary text, book historians have adopted an empirical approach to describe the development of an international book trade. ${ }^{5}$ But we know very little about the global trade in modernist books. This is significant, not only because modernism was such an influential literary movement, but also because it 
coincides with the emergence of a literary culture that we still recognize today (including celebrity culture, and the complicated relationship between marginalized authors and mainstream publishing).

My article focuses on the international expansion of modern literature in the early twentieth century through the examples of cheap reprint series published in the United States (the Modern Library), Britain (the Phoenix Library) and Continental Europe (Albatross). ${ }^{6}$ Since these series published all kinds of texts ('high,' 'low' and 'middlebrow'), I define 'modern literature' broadly, to include difficult modernist texts and popular literature. In my previous work, I have shown that cheap reprint series created in the fifteen years from 1917 to 1932 opened up new markets for texts by James Joyce, Virginia Woolf and other writers previously associated with little magazines and small presses. Books have no borders, copyright issues aside. And copyright proved a big headache for the owners of these series, leading to honest mistakes and serious disagreements. The story of modernism as an international product sold to the world is not complete without an overview of copyright issues. My central point is that copyright problems limited the reach of cheap reprint series and slowed down the international expansion of the new literature. It is not a coincidence that one of the most dynamic markets for modern literature was the Far East, where Anglophone publishers could trade books without restrictions. Continental Europe is another example of a market where the low barriers to access stimulated intense competition and the launch of innovative series such as Albatross Modern Continental Library.

\section{The Modern Library Series}

Launched in New York in 1917, the Modern Library specialised in reprinting modern texts as opposed to older 'classics." ${ }^{7}$ Albert Boni, who created the series with Horace Liveright, was primarily interested in the new literature from Europe. Since US copyright law did not protect works by foreign authors until 1891, texts by Anatole France, Thomas Hardy, Henrik Johan Ibsen and Oscar Wilde published before that date were in the US public domain and could be freely reprinted (even though they were copyrighted elsewhere). Of the first twelve titles published in May 1917, only H. G. Wells's The War in the Air was protected by copyright in the United States. For all the other titles, the Modern Library did not have to ask for permission or pay royalty payments, and could therefore keep prices low and compete directly with traditional series of reprints.

Even titles published after 1891 were not automatically protected by copyright: books had to be printed from type set in the United States or from plates made from such type to 
qualify for protection. In the case of new texts by UK-based authors, American publishers often used imported sheets of the British edition. This practice deprived foreign authors of the protection of copyright, and led reprint publishers to issue editions without any obligation to pay royalties to the authors or the original publishers. When Dodd, Mead \& Company published Norman Douglas's South Wind in the United States, they used sheets of the British edition, published by Martin Secker. In 1925, seven years after the publication of the first American edition, Horace Liveright added the title to the Modern Library and made voluntary royalty payments to the author. In his introduction to the reprint, Douglas wrote: 'it strikes me that Mr Liveright must be a bold man, for in putting this book into his Modern Library Series he seems to take it for granted that there must be a considerable number of readers with time on their hands, ready to 'give it a trial' in America. ${ }^{8}$ This introduction by the author positioned the Modern Library as a distinguished series of modern literature. After Liveright sold the Modern Library, the new owners Bennett Cerf and Donald Klopfer continued to make royalty payments until 1932, when they put an end to this agreement after a dispute with Douglas. They had bought the rights for a short text by Douglas, which they planned to publish in a fine edition under the Random House imprint. But Douglas had also sold it to another publisher in Britain, as Cerf and Klopfer discovered after paying for the rights. The Random House edition was never published, and Cerf and Klopfer stopped making payments for South Wind. With sales of the Modern Library edition passing 120,000 copies in 1952, South Wind was one of the most successful 'longsellers' in the series. ${ }^{9}$

William Henry Hudson's Green Mansions: A Romance of the Tropical Forest is another example of a bestselling work that was permanently cast into the US public domain because the first American publisher (G. P. Putnam) had used sheets from Duckworth's British edition. Twelve years later, in 1916, Alfred Knopf issued a new edition with an introduction by John Galsworthy, and promoted it vigorously. He also paid royalties as a courtesy to the author. Galsworthy's laudatory preface ('Of all living authors, now that Tolstoy has gone, I could least dispense with W. H. Hudson') undoubtedly contributed to the success of the book. ${ }^{10}$

In 1920, Horace Liveright added Green Mansions to the Modern Library list, without Knopf's permission and apparently without paying anything to the author. Advertisements for Boni \& Liveright typically used humour to create a connection with potential customers. 'Last week we received requests for review copies of Ibanez's THE CABIN and Hudson's GREEN MANSIONS, from a southern magazine devoted to home building,' declared a New York Times advertisement before adding: 'No Violet, T. S. Eliot's THE WASTE LAND, 
which is undoubtedly one of the two most talked of poetry volumes of recent months, has no bearing on the Arizona irrigation bills now before Congress. ${ }^{11}$ Boni \& Liveright did not make any difference between Eliot's difficult poem (published by the firm in 1922) and popular literature such as Green Mansions. When Bennett Cerf and Donald Klopfer acquired the Modern Library, they agreed to pay a royalty of 6 cents per copy - later raised to 8 cents - to win Knopf's good graces. ${ }^{12}$ They also marketed the book as part of a list of distinguished bestsellers (Figure 1). Far from being shunned by academia, Hudson's novel was seen as a perfectly acceptable selection for courses on contemporary literature. ${ }^{13}$ Like South Wind, Green Mansions appealed to a wide range of readers and stayed on the Modern Library list until the 1970s.



Figure 1: 'Out of the Luxury Class for the First Time' (Advertisement for the Modern Library), New York Times, 7 August 1927, p. BR15. 
In an oral history interview given at the end of his career, Alfred Knopf compared paperback publishers (such as Victor Weybright of the New American Library) with the reprint publishers of the interwar period. 'Ethics have deteriorated,' lamented Knopf before giving the example of the royalty arrangements for Green Mansions, 'the book on which our house was built.' Apparently forgetting his old conflict with Liveright, Knopf said: 'For decades we collected royalty in varying degrees from everybody who reprinted that book.' He remembered that reprint publishers would tell him:

'I want your consent. You can't withhold it because you have no legal way to withhold it. If you won't give me your consent I'll go ahead and do it anyway, but if you will give your consent I'll pay you a token royalty, or I'll pay the estate a token royalty.'

For Knopf, these gentlemen's agreements had been replaced by unscrupulous practices. 'Now, however, there is an increasing tendency to look at the law, and the minute the copyright runs out reprint ad lib. ${ }^{14}$ Although the golden age of publishing that Knopf remembered had never existed, it is certainly true that courtesy royalty payments were a feature of the interwar publishing industry.

How can we explain that reprint publishers made voluntary payments for out-ofcopyright titles? One reason was to build good relationships with the original publishers. This is particularly obvious in the case of Bennett Cerf and Donald Klopfer. When they bought the Modern Library, both were relatively inexperienced publishers still in their twenties. Alfred Knopf was more established, and making voluntary payments was a way for Cerf and Klopfer to position themselves as gentlemen publishers, as opposed to Horace Liveright, whom Knopf called a 'crook'. ${ }^{15}$ As late as 1932, Cerf - now in his mid-thirties and a wellknown name in the industry - continued to tread carefully in regards to royalty payments for Green Mansions. The National Home Library Foundation had just published an edition of the book at 15 cents (80 cents less than the price of the Modern Library edition). 'There will soon be as many editions of this book on the market as there are of Alice in Wonderland and Candide,' wrote Cerf to Knopf before suggesting a lower royalty of 5 cents per copy. Cerf added: 'I am willing, however, to leave this matter to you to decide. I realize full well how you feel about this particular book.' Cerf was aware that upsetting Knopf would make it difficult to obtain the reprint rights for other titles (in the same letter, he asked for permission to reprint Thomas Mann's 'Death in Venice’ in Great German Short Novels and Stories). ${ }^{16}$ 
The second reason for making voluntary payments was to facilitate access to foreign markets. In 1936, Knopf agents asked Macmillan - the distributor of the Modern Library in Canada - to stop selling Green Mansions in that country. ${ }^{17}$ Informed of this issue, Donald Klopfer wrote:

I don't see how the Knopf agents in Canada can claim the rights to Green Mansions. The only thing that is copyrighted is the introduction, and as long as we pay royalty to Knopf I feel sure he will not mind our selling his edition in Canada. If, however, the book is copyrighted by an English publisher, that is another story. ${ }^{18}$

Klopfer openly admitted his ignorance of copyright law in Canada, a claim that can seem surprising coming from someone who had worked in the publishing industry for more than a decade. ${ }^{19}$ In fact, the law was so complex that the Modern Library owners did not spend much time studying it, preferring instead to withdraw the edition if someone pointed out that it was illegally distributed in Canada. But what did the law actually say? As a reprint house, the Modern Library acquired reprint rights to copyrighted titles for the same territory for which the original publisher held rights. The first step was therefore to determine if the original publisher had rights to the Canadian market. If the title had first been published in the United States, the original American publisher generally had the right to sell the edition in Canada. But if the title had originally been published in Britain, the British publisher generally retained rights to the Canadian market. This is what happened in the case of Green Mansions, but it was not until 1936, thirty-two years after the publication of the first British edition, that the copyright holder asked the Modern Library to withdraw its edition. ${ }^{20}$ Although the Canadian market was at times difficult to navigate, it was often possible to sell Modern Library books without encountering any opposition.

In contrast, the British market was largely closed to American reprint publishers. When the Modern Library acquired rights from the original US publishers, this almost never included Britain. Even older works in the public domain were not necessarily freely available in this market, as translations and introductions to Modern Library books could be copyrighted in the United States. For Cerf and Klopfer, finding a way to sell their books in Britain was a constant struggle. In the late 1930s, the British publisher Hamish Hamilton distributed several Modern Library titles and sold them with his own jackets for three shillings and six pence. Because of the complexity of copyright law, Hamilton ended up announcing, and designing jackets for several titles that he could not distribute. There were 
also issues with Allen Lane, who distributed Modern Library Giants in Britain before he started Penguin Books in 1935. But Cerf and Klopfer quickly became dissatisfied with their arrangement with Lane, who was slow to pay his bills and difficult to work with. 'I think that lad is a crook,' wrote Klopfer in 1936. ${ }^{21}$ The Modern Library owners wanted Hamilton to become their exclusive British distributor, but Lane refused to cooperate and held on stubbornly to several Giants. ${ }^{22}$ The Modern Library never became a successful publishing enterprise in the UK, in part because of the competition from British series such as the Travellers’ Library published by Jonathan Cape. Hamilton once wrote: ‘English booksellers seem to prefer the Travellers' Library format, and . . . they always support a book produced in England as against an importation. ${ }^{23}$ Both Hamilton and Lane ceased distributing Modern Library books after the start of the Second World War.

Australia was another difficult market for the Modern Library, in part because British publishers considered it their own preserve. In 1926, having recently bought the Modern Library, Bennett Cerf went on a European tour, hoping to build relationships with publishers in Britain and elsewhere. After meeting with Cape, he wrote in his diary:

11.00 - Interview with Jonathan Cape who, to put it briefly, is a first-class bastard. It

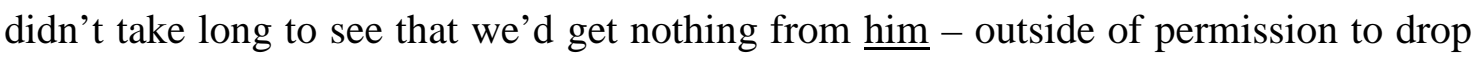
The Way of All Flesh from the M.L., + see that none of our books get into Australia + I left him with a rotten taste in my mouth. ${ }^{24}$

Jonathan Cape was eager for the Modern Library to drop Samuel Butler's The Way of All Flesh (1903), because the novel had just been included in his Travellers' Library - a series that was sold in Britain, but also in the British Empire, Canada and Australia. Like Cape, many British publishers asserted their right to the Australian market - which was sometimes a moral rather than a legal right. Ignoring Cape's demands, Cerf started selling the Modern Library there in 1927. Later that year, he suggested to an American colleague (George Oppenheimer of the Viking Press) using the same agent as he was:

The name of our new representative in Australia is Walter G. Standish . . . we are allowing Standish to give a straight $40 \%$ discount on all orders he receives, and we give him a commission of $10 \%$ on all orders either sent in by him, or received direct by us, in the whole of Australia. His first efforts for us have been a pleasant surprise. ${ }^{25}$ 
These conditions meant that Modern Library books were distributed in Australia on the same terms as to the American book trade. Obstacles remained, including copyright and censorship. Among the Modern Library titles banned in Australia in the early 1930s were Joyce’s Dubliners (1914) but also Daniel Defoe’s Moll Flanders (1722), James Huneker’s Painted Veils (1920), and Boccaccio’s Decameron (1353). However, 'in spite of copyright restrictions, Australian prudery, the Depression, and a tax of $7.5 \%$ on money sent out of the country, the scattered figures available in the Random House archives suggest that Australian booksellers added over $\$ 2,000$ a year to the ML's sales in the 1930s. ${ }^{26}$

In Continental Europe, the market for books in English had long been dominated by Tauchnitz, the Leipzig firm that had reprinted texts by Anglophone authors since 1841. After the First World War, however, Tauchnitz's monopoly started to crumble for several reasons. The wartime problems (including the lack of paper and other primary materials) left the company in a vulnerable position to face the difficult conditions of the post-war period. The hyperinflation, following the introduction of the Reichsmark in 1924, was yet another blow that contributed to Tauchnitz's decline. Rising competition from British publishers' series also threatened the firm's monopoly on the Continental market. Before the creation of the Travellers' Library and other three-and-six-penny libraries in the mid-1920s, Tauchnitz was the only continental publisher to offer recent English-language books for a small portion of their original price. For Anglophone publishers and authors, the modest rates offered by the Leipzig firm were simply better than nothing. But after 1926, there was a growing awareness that Tauchnitz books were competing with the new cheap series of modern literature. That year, the Society of Authors in Britain recommended that at least one year should separate the publication of the original and the Tauchnitz editions. ${ }^{27}$

The Modern Library could have stayed away from this already crowded European market, but this is not what happened. Paris bookshops that stocked Modern Library books included Brentano’s, W. H. Smith, and Galignani. Edward Titus (Helena Rubinstein's husband) also sold the Modern Library at his Black Manikin bookshop. Sylvia Beach was in contact with Bennett Cerf, and probably kept a stock of Modern Library books at Shakespeare \& Company. In 1927, Cerf wrote to Beach:

The Modern Library edition of James Joyce’s Dubliners [published in 1926] has been pulling some beautiful reviews. The one that arrived this morning from a Louisville, Kentucky paper is so hilariously ridiculous that I could not resist the temptation to send 
it to you. Please pass it on to Mr Joyce and if the last two paragraphs of the review make him too violent, do take some steps to calm him! ${ }^{28}$

How did Modern Library books reach bookshops in Continental Europe? From 1928 to 1934, Cerf and Klopfer worked with a publisher's representative, Henry Horwood, who was based in Paris. According to Gordon Neavill, Horwood 'assumed responsibility for ML orders received from Europe, with the exception of certain accounts (including all Italian accounts) for which he declined to accept responsibility. Rather than trying to collect from European booksellers, the ML billed Horwood for these orders at a 50\% discount. ${ }^{29}$ He also received payments from the Modern Library, on a commission basis. For the period from June 1929 to July 1930, this amounted to $\$ 100.68 .^{30}$ Sales of Modern Library books in Continental Europe reached \$1,807.61 (around 3,600 to 4,000 volumes) for the fiscal year ending 30 November 1930. The largest market was France, which represented 59\% of the total, followed by Italy, Switzerland and Denmark. Germany represented only 2\% of the total European sales $(\$ 22.42) .^{31}$ 


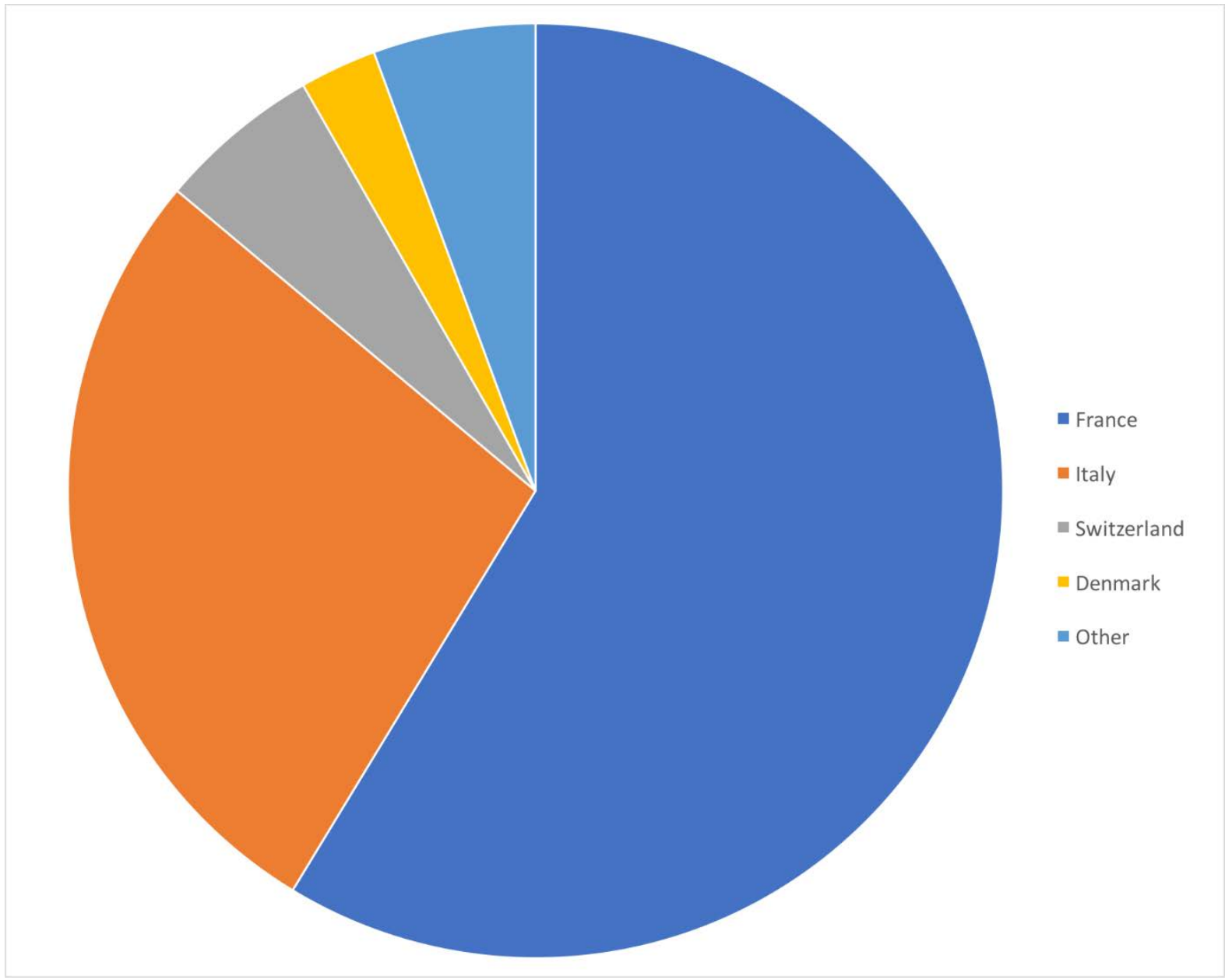

Figure 2: Modern Library Sales in Continental Europe, 1929-1930

Like Continental Europe, the Far East was a market without high barriers to access. Indeed, copyright restrictions that severely limited distribution in Britain did not apply to the 'Orient,' so the Modern Library achieved significant sales in this territory (which included the Philippines, Japan, Hong Kong, and China). By 1930, Bennett Cerf and Donald Klopfer were working with Henry Snyder, an agent who represented American publishers in Asia. A series of letters in 1930 show that Snyder received orders from the Philippine Education Company of Manila, Brewer \& Company of Hong Kong and Mitsukoshi Ltd of Tokyo, 'one of the oldest and largest department stores in Japan' which had just opened a book department. $^{32}$ The French Bookstore of Beijing, China also wanted 250 Modern Library catalogues. $^{33}$ In addition, Snyder dealt with orders for Random House, the firm that Cerf and Klopfer had created in the late 1920s.

Although the Asian market was easier to access than Britain or Canada, one major obstacle remained: censorship. In April 1934, the China News Company contacted Cerf and Klopfer: 'We have recently received a shipment of Ulysses from you and we regret to advise 
that the local police here has served us a warning not to sell this title in Shanghai, except the Chinese American Publishing Company which is under the American jurisdiction. ${ }^{34}$ James Joyce's Ulysses had recently been authorized in the United States, and published under the Random House imprint. But the book remained banned in China and many other countries. A few months later, however, the manager of the China News Company told Henry Snyder confidentially that he intended to open a branch bookstore in the French concession of Shanghai. ${ }^{35}$ Since Ulysses was not banned in the French territory, this bookshop could legally sell Joyce's novel. Shanghai was of course a very cosmopolitan city, and an important market for the Modern Library.

The few figures for Far Eastern sales in the Random House archive confirm that there was a significant demand for Anglophone books in China, but also the Philippines, Japan and Hong Kong. For the first quarter of 1938, Snyder sold Random House and Modern Library books worth $\$ 2,893.73$, up $66 \%$ from the same period in $1937 .{ }^{36}$ Bookshops that stocked these books could be found in a wide range of cities - from Tientsin and Beijing in China to Kobe, Tokyo and Yokohama in Japan. For example, sales at the French bookstore in the luxurious Grand Hotel of Beijing amounted to $\$ 130.89$ in $1934 .{ }^{37}$ These bookshops, with their cosmopolitan clientele of travellers and diplomats, contributed to the image of the Modern Library as a series that was both cheap and distinguished.

The Far East and Continental Europe were promising markets for the Modern Library, but the political and economic developments of the 1930s made it increasingly hard to sell the series there. When the Nazi persecution of the Jews began in Germany, the Modern Library's representative in Europe found it difficult to collect from Jewish booksellers. Combined with the Depression and the rising dollar, this made the situation particularly difficult for Henry Horwood. In March 1934, he wrote: 'Business [in Paris] is almost at a standstill at all of the bookstores ... Most of the Americans have left and those that are here are not buying because of the high costs. For an American living on dollars the cost of living has just about doubled during the past year.' Shortly after, Horwood disappeared. A lawyer informed the Modern Library that he had left France: 'He has apparently abandoned all business activities, and does not maintain an office in either this country or abroad so far as my investigations have disclosed. ${ }^{38}$ In the Far East, the volatile political situation in the late 1930s forced Henry Snyder to relocate to South America - a market that the Modern Library initially thought unpromising. 'Our South American business during the whole of 1938 amounted to exactly \$335.00,' wrote Lewis Miller (the Modern Library’s sales manager) to Snyder. ${ }^{39}$ However, it seems that Snyder’s relocation was eventually successful. In late 1938, 
he started to represent the Modern Library in Puerto Rico, the Canal Zone, and Havana, and then expanded his operations in Latin America. Five years later, the publisher Robert de Graff wrote to Bennett Cerf: 'You will be interested to know I saw Modern Library all over South America. ${ }^{40}$

\section{European Series: The Phoenix Library and Albatross}

In 1928, the British firm Chatto \& Windus launched a new series that shared many common points with the Modern Library. Sold for only three shillings and six pence, the Phoenix Library was positioned as a collection of modern books for a cosmopolitan audience. Charles Prentice, a senior partner at Chatto \& Windus, did not hesitate to include controversial titles, such as Wyndham Lewis's first novel Tarr. The Phoenix Library was sold to a wide public in Britain, but also in continental Europe, Japan, Canada, Australia, New Zealand and even (illegally) in the United States. In early 1928, the launch of the series was announced to major Anglophone bookshops in Paris (including Shakespeare \& Company). ${ }^{41}$ The small format of Phoenix Library books was well suited to the expatriate lifestyle. 'We intend to keep the series very select,' wrote Harold Raymond of Chatto \& Windus to one bookseller in Rome. 'Their portable size should especially appeal to your clientele, many of whom I imagine "living in their boxes," or, at any rate, afraid to accumulate bulky books. ${ }^{42}$

The Phoenix Library was also available in Japan, where Chatto \& Windus was already well established (Maruzen \& Company, a bookshop in Tokyo, had one of the firm's three largest accounts outside England). Following the suggestion made by a professor of English literature at the University of Tokyo, Chatto \& Windus placed an advertisement for the Phoenix Library in Studies in English Literature (the journal of the English Literary Society of Japan) and encouraged Maruzen to stock the series. ${ }^{43}$ It shows that the Phoenix Library targeted an increasingly international academic market.

In addition to Europe and Asia, the series was well distributed in the British dominions. As Chatto \& Windus told A. A. Milne, 'colonial buyers frequently insist on buying "cheaps” at half price. ${ }^{44}$ In Canada, therefore, the profit margin on the Phoenix Library was small. But in Australia and New Zealand, Chatto \& Windus resisted the booksellers' demand for a 50\% discount, and sold the Phoenix Library 'at ordinary English rates, which will mean to owing to costs of freightage and duty the books will be retailed over there at $4 \mathrm{~s}$. $6 \mathrm{~d} .{ }^{45}$ In an announcement to its sales representatives in the British dominions, Chatto \& Windus reminded them to push the Phoenix Library and also to pay attention to Wyndham Lewis, 'whose works are exciting very considerable attention in this 
country. ${ }^{46}$ The Phoenix Library edition of Tarr was therefore available in Canada (Lewis's country of birth) and the rest of the dominions.

Although Chatto \& Windus did not sell the Phoenix Library in the United States, some wholesalers illegally provided the books to the trade. As Bennett Cerf said, 'literally hundreds of copies of their Phoenix Library books - many of them books that are copyrighted in this country - are for sale in practically every bookstore in New York. ${ }^{47}$ Cerf had been reminded not to sell the Modern Library edition of Proust's Swann's Way in Italy (a market controlled by Chatto \& Windus), and he in turn asked Chatto \& Windus to restrict the sale of Phoenix Library books in the USA. ${ }^{48}$ It is likely, however, that Phoenix Library books continued to be sold in America, since it was difficult for publishers to prevent copies from leaking through their wholesalers.

In 1932, Cerf discussed a possible collaboration with John Holroyd-Reece, the creator of the Albatross Modern Continental Library - a new series that challenged the monopoly of Tauchnitz in Continental Europe. Instead of paying Holroyd-Reece a commission to distribute Modern Library books, Cerf proposed to sell them outright for 40 cents a copy (a $60 \%$ discount on the public price). ${ }^{49}$ Nothing came out of these conversations, because Holroyd-Reece was too busy developing his own business. ${ }^{50}$ Another issue was that, due to the high dollar, the Modern Library was more expensive than Albatross. In 1934, HolroydReece wrote again to Cerf to try (unsuccessfully) to revive the deal. Since the creation of Albatross, 'the dollar has gone down and we have a two years' experience to check up the faith in which we started. ${ }^{51}$ Holroyd-Reece gave sales figures to prove his point, rising from 20,000 copies sold in the first quarter to 70,000 copies in the seventh quarter. In other words, Albatross sold 130,000 during its first year of operation, and 180,000 copies during the three next quarters. These numbers show that there was an important market for a series that published difficult modernist texts (James Joyce's Dubliners was number 1 in the series) alongside popular literature.

Cosmopolitanism was at the centre of Albatross's brand story. Indeed, the publisher targeted readers from a wide range of national backgrounds, united only by a desire to read books in English. Because this audience was spread across various countries, it had traditionally been difficult for publishers to reach it. One advantage that Albatross had over Tauchnitz was its ability to fill in orders quickly. According to Holroyd-Reece, the promise 'to supply within 24 hours to any bookseller in some 30 countries' increased the commercial appeal of authors who had limited sales in the Tauchnitz series. ${ }^{52}$ Albatross managed to shorten its lead time thanks to an extensive distribution networks in Europe. 'While we have 
agencies all over the Continent,' Holroyd-Reece wrote in 1934, 'the centre of our distributing organisation has been in Hamburg but the expansion of our business is making us develop a new distributing centre in Paris. ${ }^{53}$ In short, these efficient distribution methods allowed Albatross to target a wider international audience.

The colourful covers of Albatross books also contributed to brand recognition across European countries. In an article entitled 'An English Tauchnitz,' The Times noted the quality of the type and paper of the series, before explaining the meaning of the colours. Yellow was for 'a psychological novel,' or essay (such as Dubliners); red for a story of adventure and crime; blue for a love story; and so on. Albatross chose different colours to indicate the type of books, wrote The Times, in order 'to save the English reader trouble at a railway or other bookstall, but also to help the foreign bookseller and reader, who will thus be able to tell at a glance the nature of each volume. ${ }^{54}$ The newspaper thus distinguished between various audiences for Albatross books: English travellers who lacked time and wanted to identify a book quickly before continuing their journey; and foreigners with limited English-language skills, who needed to be guided towards their preferred genre. In a 1937 memo, HolroydReece wrote: ' $98 \%$ of the Continental booksellers to whom we sell Albatross and Tauchnitz books cannot read English. ${ }^{55}$ And he added that the trade, having noticed that bestsellers often appeared on the Albatross list, concluded that the series selected 'the pick of American and English literature.' Interestingly, Holroyd-Reece seemed to agree with booksellers who equated commercial success with literary quality. Like the Modern Library, Albatross relied on the perception that all the books on its list ('high,' 'low,' or middlebrow') could be read by a wide audience.

To help non-English native speakers, Albatross books included a description in three different languages: English, French and German. The text sometimes varied significantly, reflecting national taste and cultural expectations. In the case of Dubliners, the English description is very factual ('No writer during the last few years has given rise to more controversy than the author of Ulysses') - whereas the French description is much more philosophical, with its reference to 'Joyce's formidable appetite to express life, all life.' Joyce's style is also contrasted to that of the naturalists, who had an 'annoying pretension to prove something.' Naturalism, a movement dominated by French writers, is not mentioned in the English and German descriptions. Likewise, Woolf's style in To the Lighthouse is described as 'a sort of English surrealism, where dream is mixed so strangely with reality.' It is probable that Holroyd-Reece wrote, or at least contributed to, these descriptions. A natural networker who seemed to know everybody in the publishing world, he was 'equally at home 
in London, New York, and all the chief capitals of Europe' and spoke 'the principal languages precisely like a native,' wrote Curtis Brown in his memoirs. 'That urbane and picturesque international' had dabbled in journalism - contributing to the Westminster Gazette, the New Statesman, the Nation and Athenaeum - before turning to publishing. ${ }^{56}$

The physical format of Albatross books confirmed this international focus. The cover of Albatross books stated 'copyright edition,' 'not to be introduced into the British Empire or the USA.' On the back cover of some editions, the price was given in three different currencies: German, French, and Italian - which gives us a sense of the market for these books. Dubliners was thus sold for 1.80 marks, 12 francs and 9 lires. At the end of the book, the colophon indicated that it was printed in Italy. The fact that The Times had presented Albatross as an 'English Tauchnitz' led to an outcry among UK publishers. 'We fear that the reviewer cannot have examined the books very carefully,' wrote one commentator. ${ }^{57}$ The publisher Thornton Butterworth also invited Times readers to take the slogan 'Buy British Goods' seriously and turn their back on Albatross and Tauchnitz. For Butterworth, the latter 'undoubtedly cuts into the Continental sales of the British Publishers, much to the disadvantage, but greatly to the supposed kudos, of the Authors. ${ }^{58}$ In a context of economic depression and rising protectionism, the Continental series were increasingly presented as enemies of the British good trade, rather than allies in the spread of Anglophone books and culture.

Albatross's cosmopolitanism and striking modern appearance positioned it as an important institution of modernism. The series did not escape the attention of Wyndham Lewis. Returning from a visit to Berlin in 1934, he wrote to Stuart Gilbert: 'The Albatross editions I saw everywhere. 59 In his autobiography Blasting and Bombardiering, Lewis celebrated the expansion of modern art, which had become part of everyday life - through the posters of E. M. Kauffer displayed in tube stations, for example. ${ }^{60}$ As a visual artist himself, Lewis undoubtedly noticed that Albatross was spreading modern design 'everywhere.' The physical format of the series fitted well with the modernity of the list, a list that reflects its owners' appetite for subversive modern fiction, with James Joyce and D. H. Lawrence occupying a dominant place.

\section{Conclusion}

In conclusion, cheap series of reprints such as the Modern Library, the Phoenix Library and Albatross had to overcome various obstacles - including copyright and censorship - to make available difficult modernist texts from New York to Shanghai. What we now call 
'modernism' was sold alongside all kinds of texts - including crime fiction. John HolroydReece was particularly proud of his Albatross Crime Club edition, which included titles from the Crime Club that Collins had set up in Britain. Publishers such as Holroyd-Reece and Cerf crossed multiple boundaries: boundaries between 'high' and 'low' literature, but also national boundaries. Collectors of Modern Library books have discovered interesting relics of the international expansion of the series. 'John I. Ely of New Haven has a copy of the ML edition of [Remy de] Gourmont's A Virgin Heart stamped with the name of a Russian emigre library in Shanghai,' wrote Gordon Neavill in the Modern Library Collector. ${ }^{61}$ With its French author, American publisher, Russian reader and Chinese bookseller, this artefact is intrinsically transnational. Shanghai was a particularly vibrant market for Anglophone books, in part because both American and British publishers could compete without copyright restrictions. We know too little about the institutions that made these modern books available to readers in the Far East and elsewhere. What is the story of the China News Company, whose manager was so eager to sell Ulysses in Shanghai? What about Maruzen \& Company, the bookshop that sold so many Phoenix Library books in Tokyo? Like Chimamanda Ngozi Adichie and other postcolonial authors who made the journey from local to global recognition, modernist writers such as James Joyce and Virginia Woolf saw their texts move out of the coterie towards the international market. But this transition did not happen magically, and the story of global institutions of modernism has yet to be written.

\footnotetext{
Notes

${ }^{1}$ Catherine Simon, 'Chimamanda Ngozi Adichie, impériale', Le Monde des livres (Paris, 5 February 2015) <http://www.lemonde.fr/livres/article/2015/02/05/chimamanda-ngoziadichie-imperiale_4570126_3260.html> [accessed 3 August 2015].

${ }^{2}$ Graham Huggan, The Postcolonial Exotic: Marketing the Margins (New York: Routledge, 2001), p. 32.

${ }^{3}$ Sarah Brouillette, Postcolonial Writers in the Global Literary Marketplace (New York: Palgrave Macmillan, 2007).

${ }^{4}$ Rebecca L. Walkowitz, Cosmopolitan Style: Modernism Beyond the Nation (New York: Columbia University Press, 2006); Jahan Ramazani, A Transnational Poetics (Chicago: University of Chicago Press, 2009).

${ }^{5}$ Alison Rukavina, The Development of the International Book Trade, 1870-1895: Tangled Networks (Basingstoke: Palgrave Macmillan, 2010); Sydney J. Shep, 'Imagining PostNational Book History', Papers of the Bibliographical Society of America, 104 (2010), 25368; Robert Fraser and Mary Hammond, Books Without Borders. Vol. 1: The Cross-National Dimension in Print Culture (Basingstoke: Palgrave Macmillan, 2008).

${ }^{6}$ The sections on the Phoenix Library and Albatross have previously been published in a slightly different form in my monograph Cheap Modernism: Expanding Markets, Publishers'
} 
Series and the Avant-Garde (Edinburgh: Edinburgh University Press, 2017). I am grateful to EUP for permission to reproduce this material here.

${ }^{7}$ For more information on the Modern Library, see Lise Jaillant, Modernism, Middlebrow and the Literary Canon: The Modern Library Series, 1917-1955 (London: Routledge, 2014); Jay Satterfield, The World's Best Books: Taste, Culture, and the Modern Library (Amherst: University of Massachusetts Press, 2002); Gordon Neavill, 'The Modern Library Series and American Cultural Life', The Journal of Library History, 16 (1981), 241-52.

${ }^{8}$ Norman Douglas, South Wind (New York: Modern Library, 1925), p. vii.

${ }^{9}$ Neavill, 'Bibliographical Notes \& Queries', Modern Library Collector, 34 (1997), 4.

10 'Our Belated Recognition of the Greatest Living Writer of Outdoor Literature,' Current Opinion May 1916, p. 349.

${ }^{11}$ Advertisement for Boni \& Liveright, New York Times, 14 January 1923, p. BR31.

12 Bennett Cerf to Alfred A. Knopf, 30 January 1929, box 110, Random House records, Columbia Rare Book \& Manuscript Library (hereafter referred to as RH).

${ }^{13}$ Green Mansions and South Wind were on the list of recommended readings for the course in modern literature that Granville Hicks was teaching at Smith College. Hicks to the Modern Library, 25 January 1928, Catalogued Correspondence (Hi-Hz), RH. See also Cerf's letter to the Heads of Departments of Comparative Literature, July 1932, box 117, RH.

${ }^{14}$ Reminiscences of Alfred A. Knopf, 1961, pp. 318-19, Columbia Rare Book \& Manuscript Library.

${ }^{15}$ Satterfield, The World's Best Books, p. 32.

${ }^{16}$ Cerf to Knopf, 16 August 1932, box 125, RH.

${ }^{17}$ E. H. Morrow (Macmillan Co. of Canada) to Donald Klopfer, 5 August 1936, box 127, RH.

${ }^{18}$ Klopfer to Morrow, 7 August 1936, box 127, RH.

${ }^{19}$ Klopfer to Morrow, 20 July 1936, box 127, RH.

${ }^{20}$ W. Copp (Copp Clark Co.) to Hugh Eayrs (Macmillan Co. of Canada), 16 July 1936, box 127, RH.

${ }^{21}$ Klopfer to Cerf, 2 June 1936, box 4, Bennett Cerf papers, Columbia Rare Book \& Manuscript Library (hereafter referred to as BC).

22 'Obviously, Lane doesn't want the books to go and will hang on to them so long as his credits permit.’ Hamish Hamilton to Cerf, 23 July 1936, box 123, RH.

${ }^{23}$ Hamilton to Cerf, 25 May 1938, box 123, RH.

${ }^{24}$ Entry for 2 July 1926, Diary: Trip to Europe; May 8 - July 1926, box 11, BC.

${ }^{25}$ Cerf to George Oppenheimer, 23 November 1927, box 131, RH.

${ }^{26}$ Neavill, 'Bibliographical Notes \& Queries', Modern Library Collector, 15 (1988), 4.

${ }^{27}$ Alistair McCleery, 'Tauchnitz and Albatross: A “Community of Interests” in EnglishLanguage Paperback Publishing, 1934-51', Library: The Transactions of the Bibliographical Society, 7 (2006), 297-316 (299).

${ }^{28}$ Cerf to Sylvia Beach, 3 February 1927, box 189, Sylvia Beach papers, Princeton

University Library.

${ }^{29}$ Neavill, 'Bibliographical Notes \& Queries', Modern Library Collector, 14 (1987), 3.

${ }^{30}$ Commissions paid to Henry Horwood (1929-1930), box 764, RH.

${ }^{31}$ Modern Library European Sales for the fiscal year ending 30 November 1930, box 145, RH.

32 Letters from Henry Snyder to Modern Library, 2 September 1930; 6 August 1930; 17 December 1930, box 766, RH.

${ }^{33}$ Letter from Snyder to Modern Library, 14 May 1930, box 766, RH.

${ }^{34}$ China News Company to Modern Library, 4 April 1934, box 155, RH. 
${ }^{35}$ Snyder to Emanuel E. Harper, 26 October 1934, box 155, RH.

${ }^{36}$ Neavill, 'Bibliographical Notes \& Queries', Modern Library Collector, 15 (1988), 4.

37 Snyder to Modern Library and Random House, 26 December 1934, box 155, RH.

${ }^{38}$ Neavill, 'Bibliographical Notes \& Queries', Modern Library Collector, 14 (1987), 4.

${ }^{39}$ Lewis Miller to Snyder, 15 March 1939, box 130, RH.

${ }^{40}$ Robert de Graff to Cerf, 27 August 1943, box 129, RH.

${ }^{41}$ Chatto \& Windus to Galignani Library, 3 February 1928, Letter book, CW A/120 (includes the following note: 'A copy of this letter sent to Miss S. Beach, Shakespeare \& Co., Paris \& Messrs Brentano's, Paris'), Archives of Chatto \& Windus, University of Reading (hereafter referred to as $\mathrm{CW})$.

${ }^{42}$ Harold Raymond to Miss Grimes (Wilson’s Library), 26 January 1928, Letter book, CW $\mathrm{A} / 119$.

${ }^{43}$ Chatto \& Windus to Arundell del Re, 11 November 1927; Chatto \& Windus to Maruzen, 11 November 1927, Letter book, CW A/119.

${ }^{44}$ Chatto \& Windus to A. A. Milne, 3 November 1927, Letter book, CW A/119.

${ }^{45}$ Chatto \& Windus to Roger Fry, 15 December 1927, Letter book, CW A/119.

${ }^{46}$ Chatto \& Windus to G. J. Hicks \& Co., 5 January 1928; Chatto \& Windus to G. J. McLeod Ltd, 5 January 1928, Letter book, CW A/119.

${ }^{47}$ Cerf to Alma Levin (Brandt \& Brandt), 29 May 1929, box 99, RH.

${ }^{48}$ Cerf to Bernice Baumgarten (Brandt \& Brandt), 7 June 1929, box 99, RH.

${ }^{49}$ Holroyd-Reece to Cerf, 2 June 1932, box 151, RH.

${ }^{50}$ Holroyd-Reece to Cerf, 27 August 1932, box 151, RH.

${ }^{51}$ Holroyd-Reece to Cerf, 4 April 1934, box 117, RH.

52 Holroyd-Reece to Raymond, 30 April 1945, Chatto \& Windus correspondence concerning The Albatross editions, CW 100/16.

${ }^{53}$ Holroyd-Reece to Cerf, 4 April 1934, box 117, RH.

54 'The Albatross: An English Tauchnitz,' The Times, 1 March 1932, 10.

${ }^{55}$ Holroyd-Reece, 'Albatross Activities in France,' 14 September 1937, box 129, William A. Bradley Literary Agency records, Harry Ransom Center, University of Texas at Austin.

${ }^{56}$ Curtis Brown, Contacts (London: Cassell, 1935), p. 178.

${ }^{57}$ Note to The Times, c. 1932, Correspondence with Chatto \& Windus concerning The Albatross, CW 48/11.

${ }^{58}$ Butterworth to W. Lints Smith, 1 March 1932, Correspondence with Chatto \& Windus concerning The Albatross, CW 48/11.

${ }^{59}$ Lewis to Stuart Gilbert, 19 June 1934, box 2, Folder 3, Stuart Gilbert papers, Harry

Ransom Center, University of Texas at Austin.

${ }^{60}$ Wyndham Lewis, Blasting and Bombardiering (London: Calder \& Boyars, 1967), p. 254.

${ }^{61}$ Neavill, 'Bibliographical Notes \& Queries', Modern Library Collector, 15 (1988), 4. 